\title{
観光地における多様な主体の地域愛着の規定因 に関する研究一ニセコ・俱知安地域を事例として
}

\author{
谷口 綾子 1 - 今井 唯 2 -原 文宏 3 - 石田 東生 4 \\ 1正会員 筑波大学大学院 システム情報工学研究科（テ305-8573 茨城県つくば市天王台1-1-1） \\ E-mail: taniguchi@risk.tsukuba.ac.jp \\ 2正会員 東日本旅客鉄道株式会社 品川保線技術センター（テ108-0075 東京都港区港南2-1-29） \\ E-mail: yui-imai@jreast.co.jp \\ 3正会員 （社) 北海道開発技術センター（テ060-0051 札幌市中央区南1条東2丁目） \\ E-mail: hara@decnet.or.jp \\ 4正会員 筑波大学大学院 システム情報工学研究科（†305-8573 茨城県つくば市天王台1-1-1） \\ E-mail: ishida@sk.tsukuba.ac.jp
}

\begin{abstract}
観光がわが国の重要政策とされ久しいが，その効果については，地域経済等への量的効果のみならず， 地域愛着の向上といった質的効果についても，検討していく必要がある。本研究では，二セコ地域を事例 とし, 地域の観光が観光客 - 地域住民の地域愛着に与える影響について分析を行った. その結果, 来訪地 域の住民との交流が観光客の当該地域愛着に影響を与えるほか，地域住民の地域愛着は近隣住民との交流 や地域活動への参加が多いほど高いことが示された。また，地域住民の観光への態度は「景観・治安」

「文化・伝統」「公共施設・サービス」「経済・商業活動」の4つの側面への評価から構成されており, 観光への態度が肯定的であるほど, 地域が好き等の選好の愛着は高まるが, 変わって欲しくないという持 続願望の地域愛着は低減する可能性が示された.
\end{abstract}

Key Words : place attachment, tourism, residents' attitudes toward tourism

\section{1. はじめに}

平成 15 年，小泉元総理大臣の第 156 回国会施政方針 演説における観光振興への言及などを契機に，わが国で も「観光」が重要な政策の柱として掲げられ，観光政策 の方針についても全面的に見直されてきた ${ }^{1)}$. 平成 19 年に制定された観光立国推進基本法では，これまでの画 一的で過度な開発に依存した観光ではなく，地域の特色 を活かした観光地づくりが目指されており，その評価に ついても経済効果や交流人口の拡大といった量的な観点 のみならず「観光」が人々の意識にもたらす質的な効果 にも目が向けられている. 観光立国推進基本計画では, その基本方針のひとつに「地域住民が地域に愛着と誇り を抱ける地域づくり」が掲げられており, 観光を通じた 地域に対する愛着意識の醸成が期待されている.

地域愛着意識の重要性については, 地理学や環境心理 学，社会心理学をはじめ，様々な分野で多く説かれてお り例えば2) - 7, 近年では, 都市計画分野でも地域づくりに おける地域愛着意識の重要性が検証されている ${ }^{8 \%, 9)}$. た
とえば，谷口らは地域愛着が高い人ほど，地域づくりの 政策に対する関心が高いことを報告しており，鈴木らは， 地域愛着が高いほど町内会活動やまちづくり活動への参 加意欲が高いことを示している. これらの既往研究から も，地域愛着意識とまちづくりは強い関係性をもってい ることが伺える.

同様に，観光についても「観光まちづくり」と言われ るように地域づくりと密接な関係がある. 大消費地の観 光資本が主導権を持ち, 結果として観光地の浮沈を握つ ている状況 ${ }^{10}$ から, 持続可能性を高め発展に転じていく ために地域住民が担う役割は大きく，この点からも観光 地における住民の地域愛着意識は観光政策のみならず地 域政策としても重要であると考えられる.

さらに，地域愛着意識の醸成が期待されるのは，そこ に住む住民だけに限らない，観光地を訪れる観光客の存 在もその地域に多大な影響を及ぼすものであり，まちづ くりの重要な主体といえる. 短期的な滞在者であっても 「部外者的立場で一時的にその地域を消費する」という 発想ではなく, 居住者同様, その地域に愛着と敬意を持 
って行動することで，地域の尊厳を守り，その地域をよ りよくしていくことにつながることが期待される．観光 客と地域住民の双方が地域に愛着を持つことは, 観光庁 が目指す「住んでよし，訪れてよし」の観光地づくりに 欠かせない要素であると考えられる。

これまで地域の観光が住民や観光客の地域愛着意識に どのような影響を及ぼしているのかについて明らかにし た研究としては, 例えばマックールとマーティンがアメ リカのモンタナ州民を対象にした調査 ${ }^{11)}$ で「観光開発に 対する態度」と「コミュニティ愛着度」との関連を捉え， 地元コミュニティに対する愛着度が高い人は, 州内の観 光開発に消極的な態度を示すとの結果を報告している.

しかし，この研究では，州レベルの観光開発と地元コミ ユニティへの愛着を結びつけており, 身近な地域での観 光開発との関連に対する研究，あるいは観光客の地域愛 着に関する研究は見当たらないのが現状である ${ }^{12-15)}$.

地域愛着意識の規定因については, 既往研究で年齢, 居住年数, 性別, 人種等の個人属性など多くの要素が指 摘されている8,16)。また, Brown et al.は，落書きなどのあ る住居や街路などの景観，地域内の物理的環境の荒廃や 地域の悪化が住民の地域愛着を低下させること，ならび に, 近隣住民との日常的な接触度が高いほど地域愛着意 識が高いことを報告している ${ }^{10}$. その他にも，景観や地 域の歴史的風景, 祭り等の地域イベントへの関心度など との関係性も指摘されているところである.

このように地域愛着意識の規定因について多くの研究 がなされているが，これらの既往研究の多くは「観光 地」に着目したものではなく対象者は住民に限られてお り, 観光地住民, 観光客の愛着意識については十分な調 查分析がなされているとは言い難い状況にある．繰り返 しになるが，深見・井出 ${ }^{10)}$ が指摘するように，観光の構 成要素は「観光資源」「観光資本」「観光客」そして 「地域住民」であり，よりよい観光地のあり方を模索す るためには，地域住民のみならず，質的な差異はあるか もしれないが, 来訪者, 寸なわち観光客の地域愛着意識 も重要であると考えられる.

本研究では, 持続可能で地域の発展につながる「観 光」のあり方を模索するため, 地域の観光が, 観光客と 地域住民の地域に対寸る愛着意識に与える影響とその影 響要因をモデル分析により明らかにすることを目的とす る.

\section{2. 研究対象地の概要}

深見・井出は観光形態を「歴史観光」「自然観光」 「テーマパーク型観光」「滞在型観光」の 4 つに分類し ている ${ }^{10)}$. 本研究では, 研究対象地を選定するにあたり,
観光客と地域住民の接触がそれほじ期待できないと考え られるテーマパーク型観光地ではなく, かつ, 観光客の

「地域愛着」により密接に関連寸ると考えられる「自然 観光」と「滞在型観光」の二つの性格を有し, 海外から の観光客と道外・道内からの観光客の双方が集う観光地 として, 北海道南西部の後志管内に位置する二セコ地域 と呼ばれる観光地域を選定した. 以下にニセコ地域の概 要について述べる.

二セコ地域(図-1)は，羊蹄山を中心とした周辺町村の 総称として一般的に認識されている. 二セコ地域は洞爺 支䇗国定公園に指定されている羊蹄山や二セコ積丹小樽 海岸国定公園に指定されているニセコ連山，さらには豊 富な温泉源など優れた自然資源を有している.また，こ れらの山々には複数のスキー場が開設されており, パウ ダースノーと言われる水分量が少なく, スノースポーツ に非常に適した良質の雪が降ることから，1950 年代か らスキーの聖地として知られてきた，そのため，宿泊施 設やスキ一場等のレジャ一施設が集中している俱知安町 の比羅夫地区が観光の中心地となっている.

1990 年代後半に入ってからは, ラフティング等の夏 季に楽しめる体験型メニューが展開され始め, 現在では 夏季の入込客数も冬季と同レベルとなっている.

2000 年代に入ると, 上質な雪を求めてオーストラリ アを中心とした外国人来訪客が急増した，その後，香港 や台湾などのアジア圈からの来訪も増加している.

なお，上述したように，二セコ地域は広範囲に渡って おり, 羊蹄山を中心とした周辺の複数の町村に跨った地 域を指す，本研究では，その中でも観光資源が多く集ま り, 宿泊施設が集中する, 二セコ地域の中核を成す二セ コ町と俱知安町の 2 町を調查対象地とした.

二セコ町は面積 197.13 平方 $\mathrm{km}$, 人口約 4,700 人で, 俱 知安町は面積 261.24 平方 $\mathrm{km}$, 人口約 15 万人の町である. 人口構成は全国平均より高齢化率がやや高い水準である 一方で, 両町とも転入・転出者数が多く, ここ 20 年ほ どを見ても年間転出入者合計值は俱知安町で人口の $15 \%$ 前後, 二セコ町で 10\%強になる. これより, 居住者の入 れ替わりが多いという特徵を有していることが伺える. 両市の主要産業は, 農業と観光業であるが, レジャー

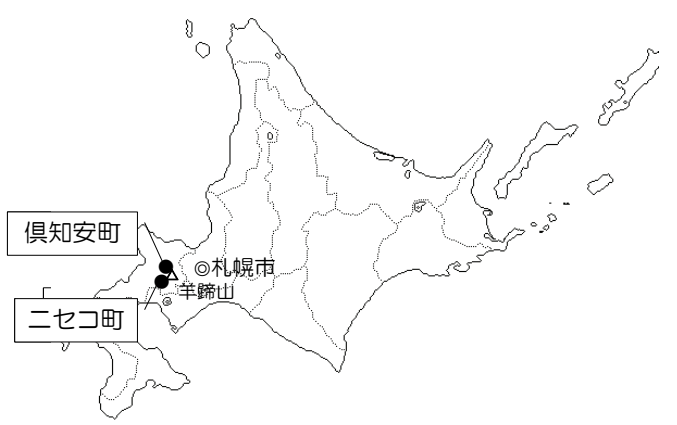

図-1 二セコ町・俱知安町位置図 
施設や宿泊施設等，観光関連施設は主に山側に集中して おり，それ以外の市街地や農業地帯では観光客との接点 が少ない住民も多い，観光客についても，北海道内から の来訪者とともに, 道外からの来訪者も多く, オースト ラリアや東南アジアなど多様な国籍の人々が集まる地域 である．このように，観光業に従事する住民と観光業に ほとんど関係のない住民が混在していること，国内外の 多様な観光客の来訪が見込めることから, 本研究では二 セコ地域を調査対象地とすることとした.

\section{3.「地域愛着意識」と「地域」の定義}

本章では，本研究における地域愛着意識と地域の範囲 について定義を行う。

これまで「地域愛着（Place attachment）」は，社会心 理学や環境心理学の分野で主に扱われてきた. Hidalgo and Hemendez ${ }^{17}$ は，環境心理学における既往研究を概観 した上で，一般的に Place attachmentを「人間と場所との 感情的なつながり」と定義している. その他の既往研究 でもこの定義に倣って，地域愛着を人と地域との間の感 情的（情緒的）な絆やつながりと定義している 0,8)18).

本研究でも同様に，地域愛着を「人と地域との間の感 情的な紏やつながり」と定義する．上記の既往研究では, その対象は居住者に限られているが，本研究では，観光 客のように一時的に滞在する主体についても，来訪地に 対する地域愛着の存在を前提にしている. これは, 観光 客は何かしらの魅力を感じて, 数ある観光地の中からそ の地域を選択して訪れていること, また, 滞在中は多少 なりとも地域との交流を持つことになることから，住民 の地域愛着と質がちがう可能性も考えられるものの, 観 光客もその土地に何らかの地域愛着を持つと考えられる からである. 複数回来訪するリピーターがいるように, 観光客の中にも「地域との感情的な絆やつながり」を感 じている人が存在するとしても不思議ではない. 実際,

Payton ら ${ }^{19}$ の研究では, 野生保護区という地区内におい て，その場所を共有する個人間の信頼及び「その場所へ の愛着」の存在が，その地域を訪問する人の「市民的な 行動(Civic action)」を促す可能性を示唆している.このこ とからも, 観光客がその訪問地一の地域愛着を持ち, そ れが来訪地での振舞いに影響する可能性があると考える ことは，論理的にあり得ることであると考えられる。

また, 地域愛着における地域の範囲について, 既往研 究ではコミュニティ活動や地区における活動の単位とな る「居住地の小中学校の学区（校区）程度の広さ ${ }^{8)} や や$ 「日常の生活行動圏 9」といった，住民の生活上で住民 同士の交流が日常的に見られる範囲と定義されている.

さらに，「観光地域」の範囲については, 住民の生活
圈とは異なり, 観光地としてひとつの名称の元，一般的 に認識されている地域とした，その範囲規模は様々であ り，ある局地的な範囲をさす場合もあれば，複数の市町 村や時には都道府県をまたぐような広範囲を指す場合も あるが，本研究では，前章で述べたように，アンケート 調査で用いる「ニセコ地域」という文言の範囲として, 一般に認知されていると考えられる俱知安町・ニセコ町 を中心とした複数の町村を跨った地域一体を対象とする こととした.

\section{4. 調査概要}

本研究では, 上述の目的を検証するため, 二セコ地域 の住民と来訪中の観光客に対してアンケート調査を行っ た. 以下に調査概要と調査項目について示寸.

\section{(1) 調査の概要}

調査の概要を表-1に示寸. 本調査の対象地は, 二セコ 地域における主要な観光資源が集まり, 来訪者の $90 \%$ が 宿泊地として選択寸る，二セコ町・俱知安町とした。

観光客に対しては, 空港とのアクセスバスの待合所や 観光客が多く立ち寄る飲食店等でアンケート調査票を直 接配布・回収した。 なお，二セコ地域は夏季と冬季で観 光客の来訪目的が大きく異なるため, 観光客については 夏季と冬季でそれぞれ調查を行った。

地域住民に対しては，二セコ町と俱知安町の世帯を無 作為に抽出し，1世帯につき2部のアンケート調査票を郵 便ポストに投函して配布し，郵送にて回収を行った。

\section{(2) 調査項目}

本調査で回答を要請した項目を表-2に示す.

まず, 地域愛着意識については, 既往研究 ${ }^{8)}$ で用いら れた選好・感情・持続願望の三つの指標, 計 12 尺度を 本研究でも使用寸ることとした(表-3). これらの地域愛 着の指標は，大谷・芳賀 ${ }^{20}$ が作成した尺度を用いた．大 谷・芳賀は環境からの情報の認知・感情の生起・評価と いったプロセスを経て人間の内部に心理的環境が形成さ れると述べ，それを踏まえた質問項目を作成している.

さらに，萩原・藤井 ${ }^{18}$ はこれらの質問項目を用いた調 査データを主成分分析を行い, 地域愛着を 3 種類に分類 している. 地域愛着（選好）は，個人的な嗜好の観点か ら当該地域を肯定的に評価する程度を意味するもの, 地 域愛着（感情）はそうした嗜好を超えて，当該地域に対 して“慣れ親しんだものに深くひかれ，離れがたく感じ る”程度を意味するもの，地域愛着（持続願望）は思考 や感情と言った現状の地域に対する認知的, 情緒的な地 域への心的関与のみを意味するのではなく, 地域のあり 
方そのものに対して“願い”を抱くという地域愛着を意 味するとしている. また，この 3 種類の地域愛着には， 醸成期間に差があるとされている. このことは，前述し た情報の認知から感情が生起するというプロセスにも当 てはまるといえる.

次に観光客の地域愛着意識の規定因と考えられるもの として「観光客の居住地」を設定した. これは, 来訪地 域との距離が離れているほど, 心理的距離が離れるため, 地域愛着が醸成されにくい可能性が考えられるためであ

表-1 調査概要

\begin{tabular}{|c|c|c|}
\hline $\begin{array}{l}\text { 調查対象 } \\
\text { 調查方法 }\end{array}$ & $\begin{array}{l}\text { 観光客 } \\
\text { 直接配布·回収 }\end{array}$ & \begin{tabular}{|l|} 
地域住民 \\
ポスデイ配布·郵送回収
\end{tabular} \\
\hline 調査実施日 & $\begin{array}{l}\text { 冬季: } 2010 / 2 / 27 \cdot 28 \\
\text { 臬: } 2010 / 7 / 28 \cdot 29\end{array}$ & $2101 / 10 / 4 \sim 25$ \\
\hline 配布数 & $\begin{array}{l}\text { 冬季: } 91 \text { 部 } \\
\text { 夏季: } 148 \text { 部 }\end{array}$ & \begin{tabular}{|l} 
俱知安町 : 5,800部 (2,900世帯) \\
二セコ町 : 2,600 部 (1,300世帯)
\end{tabular} \\
\hline 回収数 & $\begin{array}{l}\text { 冬季: } 91 \text { 部 } \\
\text { 季: } 148 \text { 部 }\end{array}$ & $\begin{array}{r}\text { 俱知安町 : 539部 (486世帯) } \\
\text { 二セコ町 : } 348 \text { 部 (322世帯) } \\
\text { 回収率: } 10.6 \%\end{array}$ \\
\hline
\end{tabular}

表-2 調查項目

\begin{tabular}{|c|c|}
\hline 個人属性 & \\
\hline \begin{tabular}{|l|} 
観光客 \\
地域住民
\end{tabular} & $\begin{array}{l}\text { 年齢 } \cdot \text { 居住地·性別·来訪回数 } \\
\text { 年齢·居住年数·性別 }\end{array}$ \\
\hline 地域愛着意 & \\
\hline \begin{tabular}{|l|} 
観光客 \\
地域住民
\end{tabular} & $\begin{array}{l}\text { 既存研究で作成された種類の地域愛着意識に関する } \\
\text { 項目についで,5段階で回答を要請 }\end{array}$ \\
\hline 地域との交 & 流度 \\
\hline 観光客 & 来訪地域の住民との交流の程度について，5段階で回答を要請 \\
\hline \begin{tabular}{|l|} 
地域住民 \\
来訪満足度
\end{tabular} & 地域の住民同士での交流の程度について，5段階で回答を要請 \\
\hline 観光客 & 調査時の来訪に対する満足度について，5段階で回答を要請 \\
\hline 地域活動の & 参加度 \\
\hline 地域住民 & $\begin{array}{l}\text { 町内会活動·まちづくり活動など地域で行われている } \\
\text { 地域活動への参加の積極性について、段階で回答を要請 }\end{array}$ \\
\hline 観光への態 & \\
\hline 地域住民 & 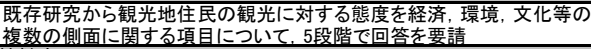 \\
\hline \begin{tabular}{|l|} 
旅行者との \\
地域住民
\end{tabular} & 接触度 \\
\hline 地域住民 & 普段の生活の中 \\
\hline
\end{tabular}

表-3 尺度の構成と信頼係数

\begin{tabular}{|c|c|c|c|}
\hline \multirow{2}{*}{ 尺度 } & \multirow{2}{*}{ 設問 } & \multicolumn{2}{|c|}{ 平均值 $\cdot \alpha$ 係数 } \\
\hline & & & \\
\hline $\begin{array}{l}\text { 地域愛着 } \\
\text { (選好) }\end{array}$ & $\begin{array}{l}\text { 地域は住みやすいと思う } \\
\text { 地域にお気に入りの場所がある } \\
\text { 地域を歩くのは気持ちよい } \\
\text { 地域ではラックできる } \\
\text { 地域の䨌囲気や土地柄が気に入っている } \\
\text { 地域が好きだ }\end{array}$ & $\begin{array}{c}3.93 \\
\alpha=0.865\end{array}$ & $\alpha=0.913$ \\
\hline $\begin{array}{l}\text { 地域愛着 } \\
\text { (感情) }\end{array}$ & $\begin{array}{l}\text { 地域は大切だと思う } \\
\text { 地域に愛着を感じている } \\
\text { 地域に自分の場所がある気がする } \\
\text { 地域に住んでみたいと感じる/ずっと住み続けたたい }\end{array}$ & $\begin{array}{c}3.53 \\
\alpha=0.769\end{array}$ & $\begin{array}{c}3.93 \\
\alpha=0.912\end{array}$ \\
\hline $\begin{array}{l}\text { 地域愛着 } \\
\text { (持続願望) }\end{array}$ & $\begin{array}{l}\text { 地域にいつまでも変わつてほしくないものがある } \\
\text { 地に域にくなってしまう悲しいものがある }\end{array}$ & $\begin{array}{c}4.04 \\
\alpha=0.743\end{array}$ & \begin{tabular}{|c|}
3.97 \\
$\alpha=0.824$
\end{tabular} \\
\hline $\begin{array}{l}\text { 地域住民との } \\
\text { 交流度 }\end{array}$ & $\begin{array}{l}\text { 地域の人々と挨拶をする機会が多い } \\
\text { 地域の人々話をする機会が多い }\end{array}$ & 0.949 & 0.928 \\
\hline
\end{tabular}

表-4 観光客の居住地による地域愛着のt検定結果

\begin{tabular}{|c|c|c|c|c|c|c|c|c|}
\hline & \multicolumn{3}{|c|}{ 日本 } & \multicolumn{3}{|c|}{ 海外 } & \multirow{2}{*}{\multicolumn{2}{|c|}{$\mathrm{t}$ 値 }} \\
\hline & $\mathrm{n}$ & M & SD & $\mathrm{n}$ & M & SD & & \\
\hline 地域愛着(選好) & 161 & 3.82 & 0.83 & 29 & 4.31 & 0.50 & 3.05 & $* * *$ \\
\hline 地域愛着(感情) & 161 & 3.44 & 0.86 & 29 & 3.61 & 0.72 & 1.02 & \\
\hline 地域愛着(持続願望) & 161 & 4.1 & 0.96 & 29 & 3.59 & 0.71 & -2.73 & $* * *$ \\
\hline
\end{tabular}

る.ここで，観光客の「滞在期間」は遠方から来た観光 客の方がより長くなることが考えられ, 害際に北海道内 からの観光客, 北海道外の国内観光客, 海外からの観光 客の順に滞在日数の平均值が(分散も大きいものの)大き くなっていた. よって, 本研究では多重共線性などの影 響を考慮し, 分散が大きい滞在期間ではなく, 海外と国 内という分類を行うダミー変数として取り扱うこととし た．なお，道内と道外の観光客を分けて集計したところ， それらに有意な差異は見られなかったため, 日本人観光 客と言うことでまとめて分析を行っている. 同様に観光 客の地域愛着には「来訪回数 ${ }^{[1]}$ も規定因になりうると 考えられる. 接触機会が多いほど，その対象物に好感を 抱くことは単純接触効果と呼称されているが, 地域愛着 もその土地との接触回数が多ければより強くなる可能性 が考えられる.

他に, 地域愛着に影響寸ると考えられる個人属性とし ては性別が挙げられる. 男性と女性では, 旅行に対して 求めるものや満足もしくは不快を感じる観点が異なるか もしれない，そのため，来訪地に対する愛着についても 影響がある可能性がある．また，来訪満足度が高い人は， 地域に対する愛着も高い可能性が考えられる.ささに, 既往研究で住民同士の関係性が良好なほど地域愛着が高 まることが示されているが 》, 観光客においても, 来訪 地域の住民との関係性が深まることでその地域に対する 愛着も高まる可能性が考えられる.

続いて, 地域住民の地域愛着の規定因として, 観光客 同様，既往研究でも関係性が指摘されている個人属性 （年齢，居住年数，性別）と，近隣住民との交流度を設 定した. また, まちづくり活動への参加が地域愛着意識 の醸成に影響があると示唆する研究結果の報告もあり ${ }^{8)}$, 観光とまちづくりの関係性も報告されていることから, 本調査では地域活動への参加度についても回答を要請す ることとした ${ }^{[1]}$.

なお，地域愛着意識と地域住民との交流度については, 5 段階評定とし, 尺度両端の定義「とてもそう思う」を

表-5 観光客の性別による地域愛着のt検定結果

\begin{tabular}{|c|c|c|c|c|c|c|c|}
\hline & \multicolumn{3}{|c|}{ 男性 } & \multicolumn{3}{|c|}{ 女性 } & \multirow{2}{*}{$\mathrm{t}$ 値 } \\
\hline & $\mathrm{n}$ & M & $\mathrm{SD}$ & $\mathrm{n}$ & M & $\mathrm{SD}$ & \\
\hline 地域愛着(選好) & 88 & 3.99 & 0.74 & 80 & 3.86 & 0.77 & 1.09 \\
\hline 地域愛着(感情) & 90 & 3.57 & 0.79 & 81 & 3.48 & 0.77 & 0.79 \\
\hline 地域愛着(持続願望) & 86 & 4.07 & 0.78 & 80 & 4.01 & 0.98 & 0.42 \\
\hline
\end{tabular}

表-6 地域愛着とその規定因の相関分析結果（観光客）

\begin{tabular}{|c|c|c|c|c|c|c|c|c|c|}
\hline & \multicolumn{3}{|c|}{ 地域愛着（選好） } & \multicolumn{3}{|c|}{ 地域愛着(感情) } & \multicolumn{3}{|c|}{ 地域愛着(持続願望) } \\
\hline & $\mathrm{n}$ & 相関係 －－－－ & & $\mathrm{n}$ & 相関係娄 & & $\mathrm{n}$ & 相関係 & \\
\hline 年齢 & 219 & 0.10 & * & 218 & 0.14 & & 213 & 0.04 & \\
\hline 地域住民との交流度 & 219 & 0.39 & **** & 217 & 0.37 & $* * *$ & 213 & 0.14 & ** \\
\hline 来訪回数 & 199 & 0.06 & & 200 & 0.18 & $* * *$ & 193 & 0.23 & *** \\
\hline 来訪満足度 & 211 & 0.53 & $* * *$ & 208 & 0.32 & $* * *$ & 214 & 0.41 & $* * *$ \\
\hline 地域愛着(選好) & & & & 212 & 0.71 & *** & 209 & 0.51 & $* * *$ \\
\hline 地域愛着(感情) & & & & & & & 207 & 0.51 & $* * *$ \\
\hline
\end{tabular}


5, 「まったくそう思わない」を 1 として，複数の設問 項目への評定の平均值を尺度として用いている. 観光客 と地域住民それぞれの尺度の平均值について表-3 に示 す．尺度の信頼性については，表-3 に示した信頼性係

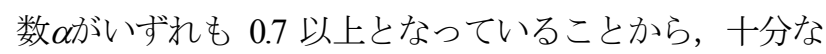
信頼性が得られたと判断した. なお，夏季と冬季の差異 についてはいずれも有意な差は認められなかったため, 本研究では夏季と冬季を合わせて一つのデータとして分 析を行うこととした.

\section{5. 観光客の地域愛着意識 分析結果}

\section{（1）地域愛着意識の規定因の探索的検証}

\section{a) 居住地別 - 性別 地域愛着の平均值の検定}

前章で述べた地域愛着意識に影響を及ぼす規定因と考 えられる居住地別に, 地域愛着の三要因の平均値の差の t検定を行った結果を表-4に示す，居住地の影響につい て，国内からの来訪者よりも，海外からの来訪者の方が 地域愛着（選好）が高いといら結果が示された．一方で, 地域愛着（持続願望）は国内来訪者の方が海外来訪者よ りも高いことが示された. また，いくつかの既往研究で は, 女性の方が地域への愛着が高いと報告されているが, 本研究で得られた調査からは性別による差異は有意とは ならなかった（表-5）.

\section{b) 相関分析}

次に, 来訪に対寸る意識や来訪回数の地域愛着一の影 響を明らかにするため，尺度間の相関分析を行った結果 を表-6に示す．表-6より，来訪満足度ならびに地域住民 との交流度と, 三つの地域愛着意識にはそれぞれ有意な 相関関係が確認された. 来訪満足度が高いと，地域のこ とが「好きだ」という好意を表す，より表層的な初期段 階の地域愛着(選好)が高まることはもちろん, 地域に

「自分の居場所がある」や「変わってほしくない」とい う，来訪地域を第三者的立場ではなくより身近に感じる 気持ち，すなわちより深い地域愛着が高まることにつな がっているものと考えられる.

さらに，地域住民との交流が多ければ多いほど，来訪 地域との心理的距離が縮まり，より深い地域の魅力を認 識し, より深い段階の地域愛着(感情)之地域愛着(持続願 望)が高まった可能性が考えられる.

また，来訪回数が多くなるほど，地域愛着（感情）と 地域愛着（持続願望）が高まることが示されたことから， 来訪を重ねるほどに地域に対する深い段階の愛着意識が 醸成されることが示唆された.

\section{（2）地域愛着意識の構造モデルの推定}

次に, 前節の分析結果を踏まえ, 観光客の地域愛着意
識の構造について図-2に示す仮説を設定し，共分散構造 分析によるモデル構造の推定を行った.

仮説では，地域愛着に影響を及ぼす要因として，前節 の分析結果で有意差が認められなかった性別を除き, 観 光客の居住地(外国人ダミー), 年齢, 来訪回数, 来訪満 足度, 地域住民との交流度を変数として設定した。

さらに, 観光客の来訪目的によって, 地域愛着の程度 も異なる可能性が考えられる. 例えばスキーを目的にし た来訪の場合, 基本的にスキー場というひとつのレジャ 一施設内ですごす時間が主となることが予想される。 そ のため, 来訪「地域」に対する愛着の醸成にはつながり にくい可能性も考えられる. このように, 来訪目的によ る地域に対する愛着意識の差異も検証するため, 二セコ 地域の代表的な観光資源である，「景観」「温泉」「入 キー」をそれぞれダミー変数として設定した．また，前 節で示したように, 地域住民との交流度は地域愛着の高 さに影響があることが示唆されたことから，「地域の人 とのふれあいをを目的とした来訪であるかについても来 訪目的ダミ一変数として加えた.

また，地域愛着の構造については，前述したように既 往研究から, 地域愛着 (選好) から地域愛着 (感情) と 地域愛着（持続願望）へと段階的に進む可能性が示唆さ れている，そのため，本稿でも図-2に示寸ように，地域 愛着（選好）から地域愛着（感情）・地域愛着（持続願 望）へのパスを仮定した.

図-2に示寸仮説に基づき, 当初は地域愛着の三要素に 向けた全てのパスを仮定し，何度か探索的に推定を行い， 有意でなかったパスを削除しつつ試行錯誤で共分散構造 分析(AMOS)を行った結果, $10 \%$ 水準未満で統計的に有 意，あるいは有意傾向であった因果パスを図-3に示寸。 モデル全体の適合度は高いとは言えないが，本研究では モデル全体の構造の検討と言うよりはむしろ, 各変数間 の因果関係に着目した考察を行うことに主眼をおくこと とする.

まず, 既往研究で述べられている通り, 本研究でも地 域愛着（選好）から地域愛着（感情）・地域愛着（持続 願望）への正のパスが確認された.

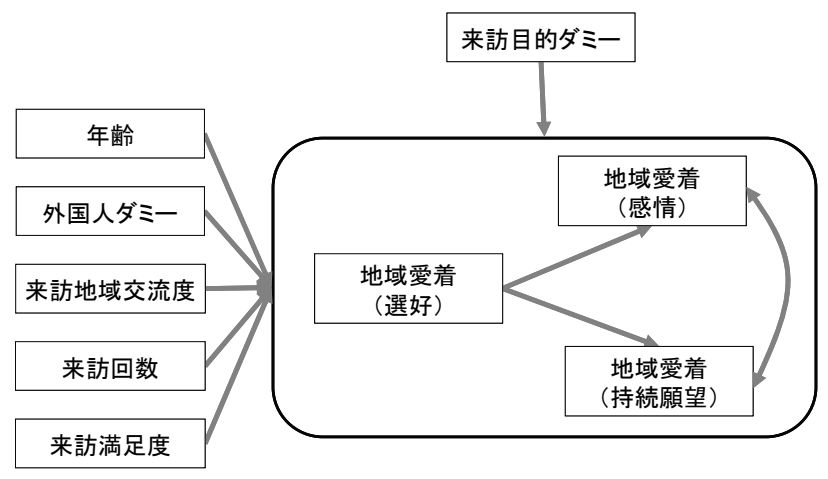

図-2＼cjkstart観光客の地域愛着意識の構造モデル（仮説） 


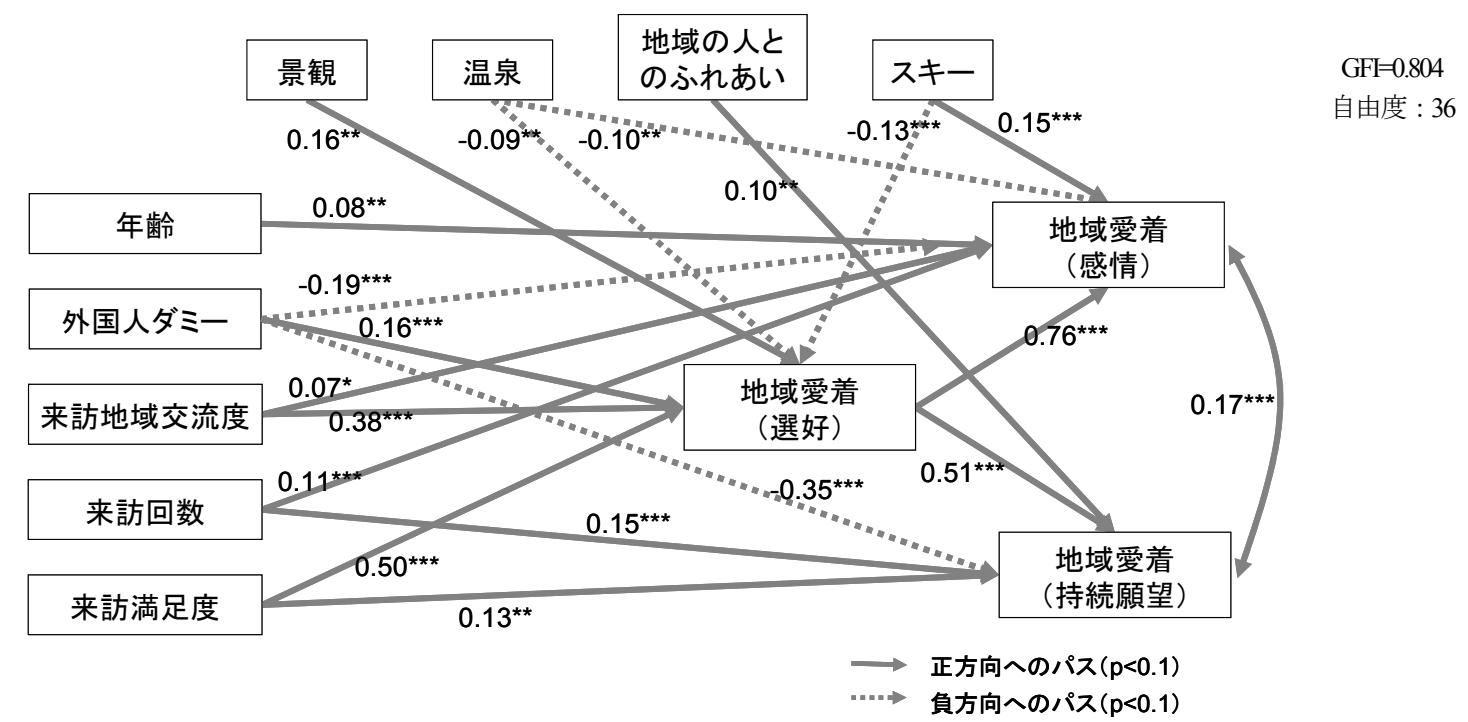

図-3 観光客の地域愛着意識の構造モデル（推定結果）

年齢は地域愛着（感情）に対してのみ有意な正のパス が認められた。 また，外国人は日本人に比べて，地域愛 着（選好）は有意に高くなる反面，地域愛着（感情）と 地域愛着（持続願望）は有意に低い(ネガティブなパス が示された)という結果となった，外国人は，日本人に 比べて来訪地域に対して好ましいと感じる地域愛着（選 好）が強い傾向があることが示唆されたが，これはニセ コ地域では外国人用の施設が充実していることなどが影 響している可能性が考えられる。，一方で，二セコ地域は 日本に属する地域であるため，当該地域に対して「自分 の居場所を感じる」といった所属意識や地域を「大切と 感じる」という地域に対する感情で構成される地域愛着 (感情) や，当該地域の持続的な存続に対しての願いを 表す地域愛着（持続願望）は，外国人よりも日本人の方 が高くなっていると考えられる.

次に，来訪地域住民との交流度は，地域愛着（選好） と地域愛着（感情）に対して有意な正のパスが認められ た．このことから，地域住民との交流機会が増えると， 地域愛着（選好）・地域愛着（感情）が高まることが示 唆された．また，地域愛着（持続願望）に対する直接的 なパスは有意とならなかったものの, 地域愛着（選好） から地域愛着（持続願望）に対するパスが有意なため, 来訪先の地域住民との交流によって地域愛着（選好）が 高まることで，地域愛着（持続願望）の醸成へとつなが る可能性が示されたと言える. さらに，来訪回数につい ては，地域愛着（感情）と地域愛着（持続願望）に対す る有意なパスが認められた。一方で, 地域愛着（選好） では有意なパスはない。これらのことから, 地域愛着 (感情) と地域愛着（持続願望）は来訪を重ねるほどに 高まる意識だが，地域愛着（選好）は初来訪の時点で, ある程度固定され，それ以降来訪を重ねても高まりにく い愛着意識である可能性が示されたと言える.これは,
既往研究で報告されているように, 地域愛着（感情）・ 地域愛着（持続願望）は, 地域愛着（選好）に比べて, 変化に長期間の時間を要することを支持する結果である と考えられる。

来訪満足度は, 地域愛着（選好）と地域愛着（持続願 望）に対して有意となった。 この変数についても，地域 愛着（感情）に対して有意な結果は得られなかったが, 来訪回数同様, 地域愛着（選好）から地域愛着（感情） に対してパスがあるため，間接的に地域愛着（感情）に 正の影響を与えることが示唆された。

次に，来訪目的に関する分析結果について述べる. 自 然景観ダミ一は, 地域愛着（選好）に対して正のパスが 認められた.このことから，二セコ地域の自然景観に興 味を持って来訪する観光客は，地域愛着（選好）が高く, 間接的に将来的に地域愛着（感情）や地域愛着（持続願 望）の醸成につながる可能性が示された. 地域の人との ふれあいダミーは, 地域愛着（持続願望）にのみ，有意 な正のパスが確認された．来訪に際して地域住民との交 流を目的として来訪する人は, 地域愛着（持続願望）が 高いことが示された，温泉ダミーでは，地域愛着（感 情）・地域愛着（持続願望）に有意な負の影響が見られ た. この理由について, 本研究の調査分析からは断定す ることは困難であるが，考えられる要因として，例えば 観光資源の地域独自性が挙げられる. 温泉は二セコ地域 の貴重な資源ではあるが，温泉施設そのものに対しては， 自然景観や地域住民と比較するとその地域の独自性は薄 いと考えられる．また，「温泉」は長年日本人の旅行目 的の第一位であるが，温泉施設は日本国内に多数存在す ること，ならびに，泉質も地域性というよりはその温泉 独自のものであることが多いことなどから，その地域一 の愛着というよりは「温泉に入る」という行為への選好 が強い可能性も考えられる. 
表-7 地域愛着と各変数の相関分析結果（地域住民）

\begin{tabular}{l|ccc|ccc|ccc}
\hline & \multicolumn{2}{|c|}{ 地域愛着(選好) } & \multicolumn{2}{|c|}{ 地域愛着(感情) } & \multicolumn{2}{|c|}{ 地域愛着(持続願望) } \\
& $\mathrm{n}$ & 相関係数 & $\mathrm{n}$ & 相関係数 & $\mathrm{n}$ & 相関係数 \\
\hline 年齢 & 764 & 0.09 & $* * *$ & 778 & 0.24 & $* * *$ & 786 & 0.02 & \\
居住年数 & 731 & 0.09 & $* * *$ & 744 & 0.32 & $* * *$ & 752 & 0.00 & \\
地域住民との交流度 & 760 & 0.40 & $* * *$ & 773 & 0.42 & $* * *$ & 780 & 0.28 & $* * *$ \\
地域活動参加度 & 681 & 0.31 & $* * *$ & 690 & 0.38 & $* * *$ & 700 & 0.25 & $* * *$ \\
\hline 地域愛着(選好) & & & & 753 & 0.82 & $* * *$ & 757 & 0.62 & $* * *$ \\
地域愛着(感情) & & & & & & & 768 & 0.57 & $* * *$ \\
\hline
\end{tabular}

表-8 地域住民の性別による地域愛着のt検定結果

\begin{tabular}{|c|c|c|c|c|c|c|c|}
\hline & \multicolumn{3}{|c|}{ 男性 } & \multicolumn{3}{|c|}{ 女性 } & \multirow{2}{*}{ t値 } \\
\hline & $n$ & M & SD & $n$ & M & SD & \\
\hline 地域愛着(選好) & 398 & 3.91 & 0.86 & 314 & 3.94 & 0.87 & -0.57 \\
\hline 地域愛着(感情) & 397 & 3.94 & 0.94 & 330 & 3.92 & 0.91 & 0.2 \\
\hline 地域愛着(持続願望) & 406 & 4 & 0.98 & 325 & 3.97 & 1.01 & 0.4 \\
\hline
\end{tabular}

旅行目的が「スキー」であることも地域愛着（選好） に対して負の影響が見られた．スキーも概ねひとつの施 設内で行うものであり，雪質や施設の質などの違いはあ るものの，いわゆる「地域性」との関係が比較的淡いた め，温泉同様，二セコ地域そのものへの愛着の䁔成には つながりにくい可能性が考えられる。しかし，スキーに ついては，地域愛着（感情）に対して有意な正のパスが 認められる．この要因については，本研究における調査 分析から特定することは困難であり，今後，検討すべき 点であると考えられる.

\section{6. 地域住民の地域愛着と観光への態度分析結果}

\section{（1）地域愛着意識とその規定因の相関分析}

次に，観光客を受け入れる側の地域住民の地域愛着意 識に影響を与える規定因について探索的に分析する.

地域住民の地域愛着に影響を及ぼす影響として，「年 齢」「居住年数」「地域住民との交流度」「地域活動一 の参加度」の4変数について，相関分析を行った，その 結果，表-7に示寸ようにそれぞれ地域愛着との有意な相 関関係が認められた。ただし，年齢と居住年数において の夕地域愛着（持続願望）との関連性は見られなかった。

また，性別については観光客同様，地域愛着に性差は 見られなかった（表-8）。

\section{（2）「観光への態度」尺度の構成}

続いて，地域住民の観光への態度が地域愛着に及ぼす 影響について分析を行った。ここに，「態度」とは，人 の社会的行動を予測・説明するために考案された仮説的 構成概念の1つであり，心理学では一般に「ある行動を 実行する事についての感情的好ましさ」等と言った意味 で用いられる.よって本研究では，「钼光への態度」を
「個々人が観光全般に対して抱く感情的好ましさ」と定 義する。

まず，地域住民の観光に対する態度の尺度構成の検討 を行った．観光地に住む住民の観光に対寸る態度につい ては，これまで多くの既往研究で様々な指標による計測 が試みられている例えは21)-20. 佐々木は既往研究をレビュ 一し，心理指標を「経済」「環境」「文化」「生活」

「行政」と5つの側面からの評価に分類している27)。本 研究では被験者の負担を軽減するため，百数十にわたる

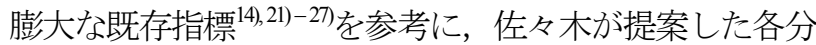
類からできる限り偏りがないよう配慮しつつ 34の指標 を選択し（表-9），これらの指標を因子分析することに より「観光への態度」の尺度を構成することを試みた。

分析に用いる各指標間に関連性が全くないとは考えに くいため，本研究では斜交回転（プロマックス法）を用 いた. その結果，表-9に示す7成分(固有值1.0以上)が抽出 された．ここで，分析に際しては，指標の中で観光に対 してポジティブな尺度とネガティブな尺度が混在してい る指標については，全てポジティブな方向に揃うよう， ネガティブ方向の指標の評価を逆転させて分析を行って いる.

表-9に示すとおり，7つの因子が抽出されたが，それ ぞれについて信頼性分析を行った結果，第1因子から第4 因子までの尺度で信頼係数 0.65 以上となり，十分な信頼 性が得られたと判断し，この4因子の平均值を「観光一 の態度」尺度の構成要素として用いることとした。

ここで，第 1 因子を構成する尺度は，旅行者や移住者 の流入により引き起こされる自身の生活上への影響につ いての評価と解䣋できる，上述のように，尺度は全て観 光に対して肯定的な態度となるように，逆転済みのため， 第 1 因子は「観光が景観，治安，交通状況に与える影響 に対する好意的評価度」と名付ける.

次に，第 2 因子は，旅行者や移住者がその地域の文化 や伝統に与える影響に関する項目であったため「観光が 文化交流，歴史遺産等に与える影響に対する好意的評価 度」と名付ける。

第 3 因子はいずれも公共サービスについて述べられて いるので，「観光が公共施設・サービスに与える影響に 対寸る好意的評価度」と名付ける。 
表-9「観光への態度」尺度の因子分析結果 と信頼性係数 $\alpha$

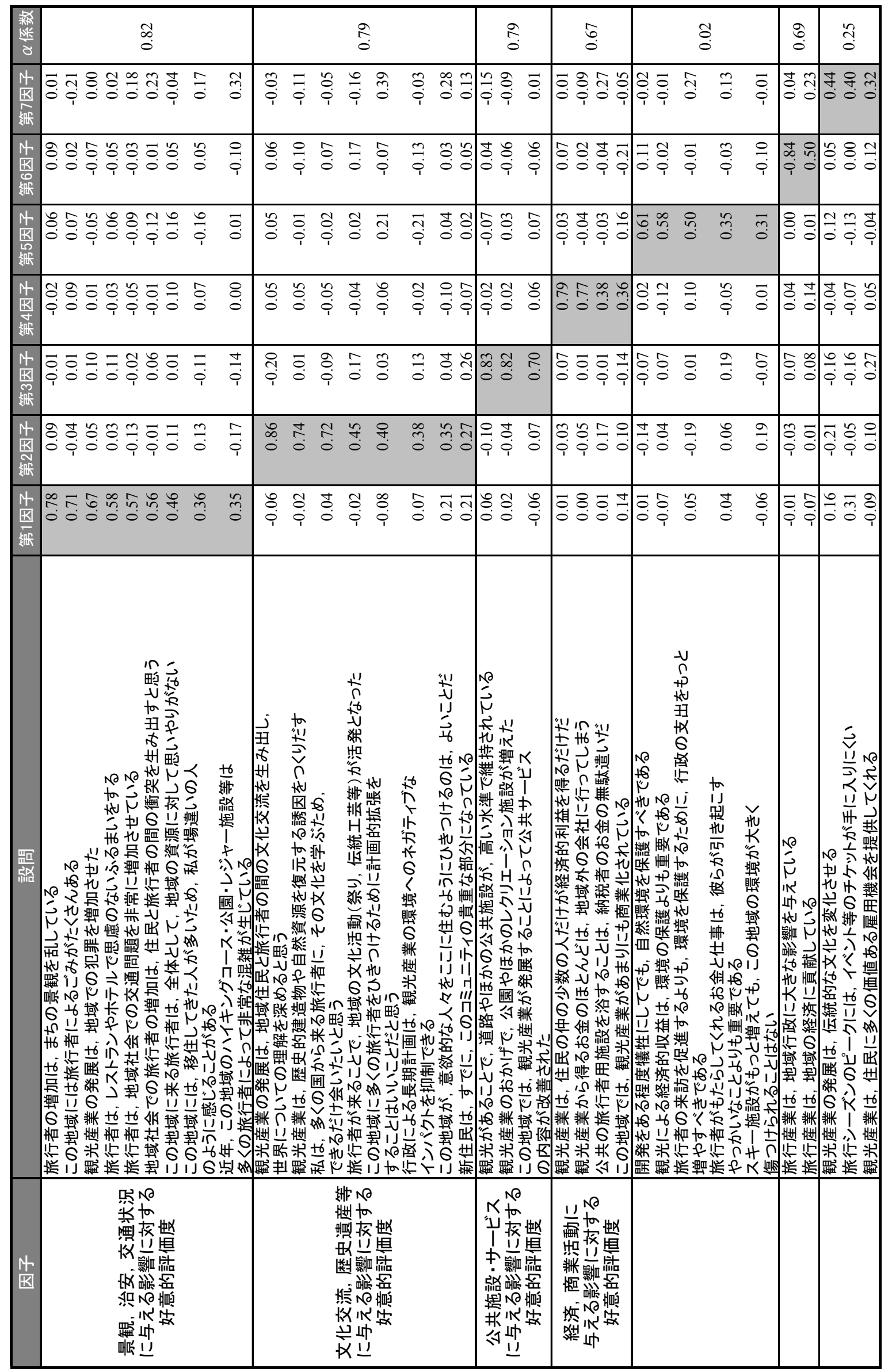




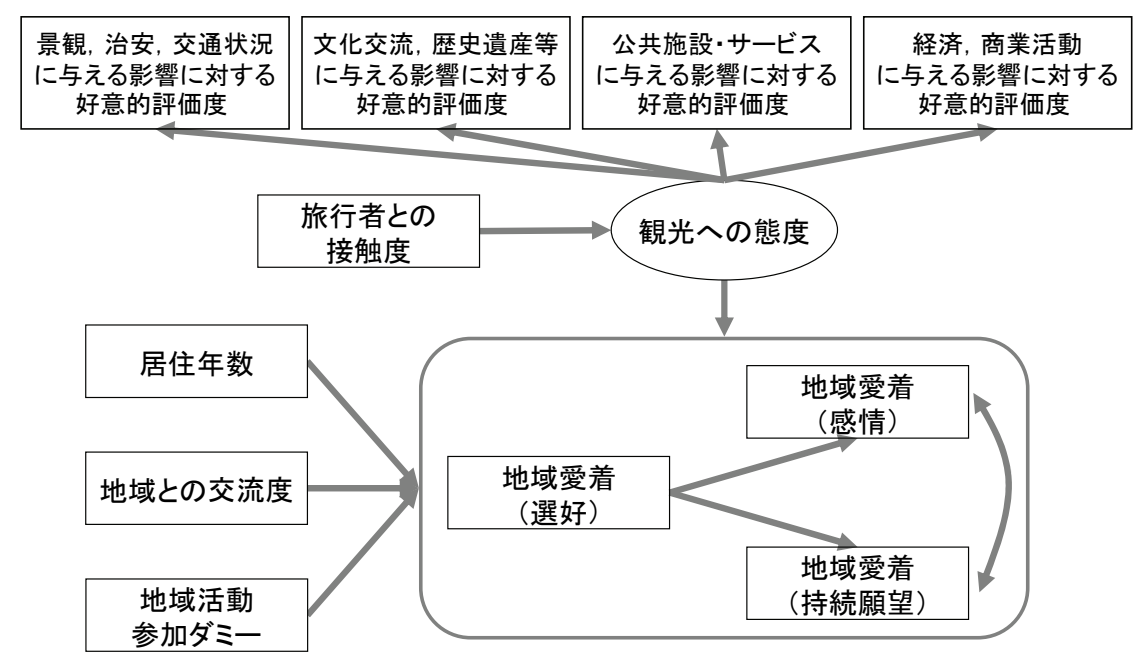

図-4 地域住民の地域愛着意識の構造モデル（仮説）

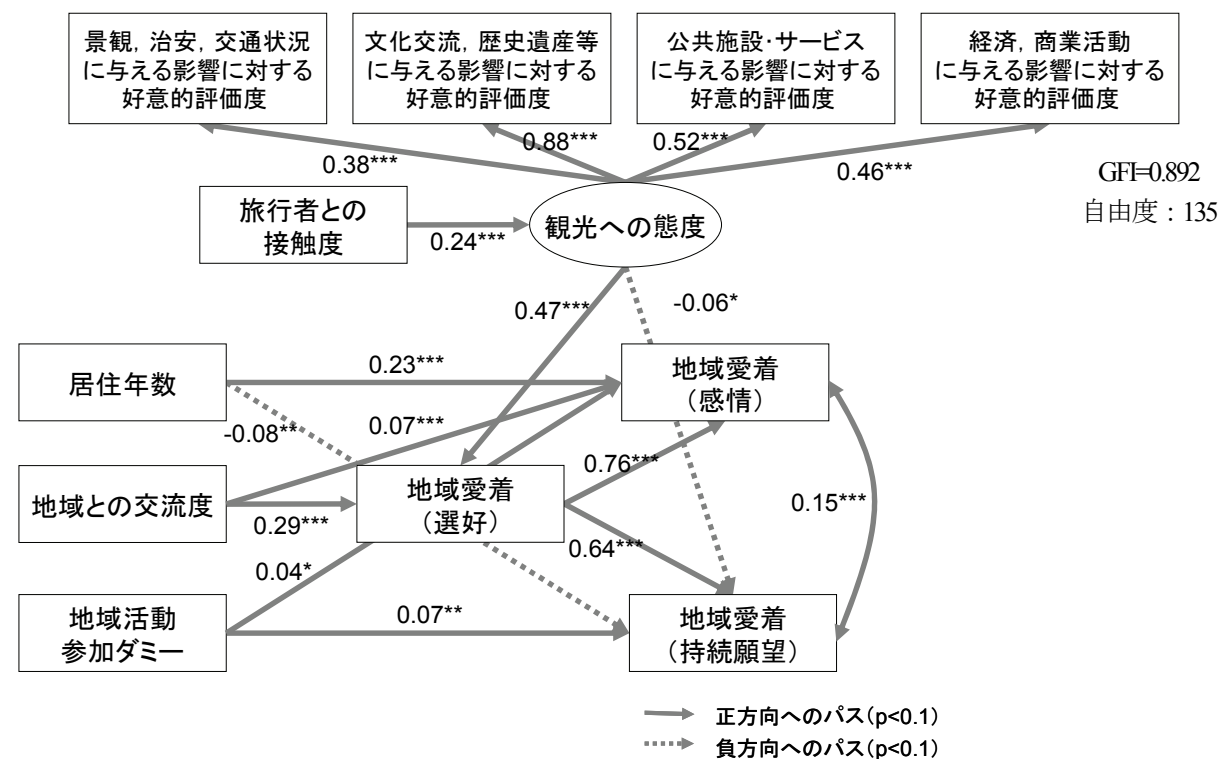

図-5 地域住民の地域愛着意識の構造モデル（結果）

第 4因子は，観光産業によって得られる経済効果に関す る項目で構成されているため，「観光が経済，商業活動 に与える影響に対する好意的評価度」と名付ける．ここ で, 先に述べたとおり, 各尺度は全て観光にポジティブ な方向にそろえてある都合上，因子名は観光にポジティ ブなものとなっている.

次節では，相関分析によって地域愛着との関連性が示 唆された居住年数や地域住民との交流度等の変数と, 因 子分析により抽出した観光に対する地域住民の態度(4 指 標が地域愛着に及ぼす影響について分析を行う。

\section{(3) 共分散構造分析}

(1)節，(2)節の結果を踏まえ，観光客の地域愛着意識 の構造の推定と同様，共分散構造分析を用いた地域住民 の地域愛着の構造モデル推定を行う.

(1)節における相関分析から，年齢，居住年数，地域
住民との交流度，地域活動への参加度の4変数について， 地域愛着意識との関連性が示唆された。それを踏まえて, 居住年数, 地域住民との交流度, 地域活動への参加度を 地域愛着意識への影響要因として設定する．なお，年齢 については，地域に対する愛着意識は一般的に地域と関 わった時間が長いほど高まると考えられ，相関係数を見 ても年齢と居住年数は互いに相関が強いことが伺える. そのため，本分析では年齢ではなく，居住年数のみを規 定因として設定した.

さらに，前節で構成した「観光への態度」の4尺度を 用いて，観光地住民の観光への態度が地域愛着意識に対 して与える影響を明らかにすることを試みた。また，二 セコ地域には観光客との接点が多い住民とほとんじ接触 する機会を持っていない住民が存在する．観光客との接 触機会の程度は「観光への態度」に大きな影響を与える と考えられるため，「普段の生活の中で観光客と話寸機 
会が多い」という項目に対して，「とてもそう思う」か ら「全くそう思わない」までの5段階で回答を要請し, 観光への態度に対寸る影響要因と仮定した. 以上の仮説 をまとめたものを，図-4に示す．

図-4に示寸仮説に基づき, 当初は地域愛着の三要素に 向けた全てのパスを仮定し，何度か探索的に推定を行い， 有意でなかったパスを削除しつつ試行錯誤で共分散構造 分析(AMOS)を行った結果, 有意確率 $10 \%$ 水準未満で統 計的に有意，あるいは有意傾向であった因果パスを図-5 に示す，図-5より，観光客での結果同様，地域住民でも 地域愛着（選好）から地域愛着（感情）, 地域愛着（持 続願望）への因果パスが確認され，既往研究における知 見を追試することができた.

次に，居住年数は地域愛着（感情）に対しては有意に 正の影響を及ぼしているが，地域愛着（持続願望）に対 しては，負の影響を及ぼしているという結果となった. しかし，地域愛着（持続願望）は地域愛着（選好）から 標準化係数 0.64 と比較的大きな正の影響を受けている.

また，(1)節で行った相関分析の結果でも，地域愛着 (持続願望) のみ，居住年数と有意な相関関係が見られ なかったことも考慮すると，必ずしも居住年数が短いほ ど地域愛着（持続願望）が低くなるという結果を示して いるとは言い難いと考えられる，ただし，他の2種類の 地域愛着には負の直接効果は見られないことから, 地域 愛着（持続願望）はそれ以外の地域愛着とは異なる特質 を持つ可能性が示唆されたと言える.

ここで, 居住年数と地域愛着の関係をより詳細にみる ため, 居住年数を 10 年ごとに区切りクロス集計してみる と, 居住年数が 30 年 40 年の住民の地域愛着（持続願 望）が最も低くなっていることがわかる（表-10）。こ の居住年代は, 地域愛着（選好）についても他の年代に 比べ低いほか, 地域愛着（感情）は 10 年に次いで低い ことがわかる. この層は，1970１980 年の間にニセコに 移住してきたということになる. 1960 年代〜80 年代の 二セコ地域はスキーリゾート地として発展を遂げていた 時代で，地域の変動も大きかった。また，この時期は 1980 年代初頭からのペンションブームの少し前の頃で, 旧住民と移住者間の溝は大きかったとされている ${ }^{28)}$.

当該地域での居住年数が長い場合でも，その地域に対 して否定的な感情を抱いている場合には, 地域愛着が醸 成されにくいことが既往研究で示されており ${ }^{29)}$, 本調査 で収集したサンプルのみから断定は出来ないが，このよ うな社会的背景が少なからず影響を及ぼしている可能性 は否定できない.

また, 地域活動参加の有無については, 地域愛着（感 情）・地域愛着（持続願望）に有意な結果が得られた.

観光への態度については，4因子全てに対して正の有 意なパスが確認された，その中でも，文化交流，歴史遺
表-10 居住年数と地域愛着意識のクロス集計表

\begin{tabular}{|c|c|c|c|c|c|c|c|c|c|}
\hline \multirow{2}{*}{$\begin{array}{l}\text { 居住 } \\
\text { 年数 }\end{array}$} & \multicolumn{3}{|c|}{ 地域愛着(選好) } & \multicolumn{3}{|c|}{ 地域愛着(感情) } & \multicolumn{3}{|c|}{ 地域愛着(持続願望) } \\
\hline & $\mathrm{N}$ & $\mathrm{M}$ & SD & $\mathrm{N}$ & $M$ & SD & $\mathrm{N}$ & $M$ & SD \\
\hline 10年 & 244 & 3.91 & 0.92 & 241 & 3.64 & 1.00 & 244 & 3.95 & 1.06 \\
\hline 20年 & 82 & 3.91 & 0.90 & 81 & 3.92 & 0.82 & 83 & 4.18 & 0.97 \\
\hline 30年 & 83 & 3.74 & 0.94 & 83 & 3.80 & 1.00 & 84 & 4.04 & 0.96 \\
\hline 40年 & 81 & 3.66 & 0.85 & 86 & 3.83 & 0.86 & 86 & 3.74 & 1.12 \\
\hline 50年 & 79 & 3.96 & 0.85 & 86 & 4.11 & 0.87 & 86 & 3.98 & 1.10 \\
\hline 60年 & 68 & 4.05 & 0.65 & 71 & 4.29 & 0.69 & 72 & 3.94 & 0.75 \\
\hline 70年 & 51 & 4.13 & 0.78 & 52 & 4.39 & 0.72 & 54 & 3.95 & 0.95 \\
\hline 80年 & 43 & 4.24 & 0.81 & 44 & 4.67 & 0.53 & 43 & 4.12 & 0.96 \\
\hline
\end{tabular}

産等に与える影響に対する評価は係数が 0.88 と最も高 く, 地域住民の観光への態度形成に最も大きな影響を与 える可能性が示された. また, 旅行者との接触度が観光 への態度へ正の影響を与えているため, 普段の生活の中 で旅行者との交流機会が多いほじ，観光に対する態度は 肯定的なものになることが示唆された.

さらに，観光への態度が地域愛着（選好）に対しては 正の影響を与えることが示された一方, 地域愛着（持続 願望）に対しては負の影響を与える有意傾向が示された. 地域愛着 (持続願望) は, 言い換えると「地域が変化し てほしくない」という願望であるともいえる。そそれに対 して, 観光は地域外からの旅行者が常に入れ替わり滞在 したり，外部資本が流入するなど，地域の変化をより大 きくする要素を多分に含んでいる. 特に, 近年のニセコ 地域は，外国人来訪者や海外資本による大規模開発が進 んでいる最中であり, 観光地としての大きな転換期を迎 えている. そのため，観光に対する態度が肯定的なほど， 地域の変化に対しての拒絶意識が低いという分析結果は 論理的に整合するものと考えられる.ただし，これにつ いても居住年数と同様, 係数が-0.06 と小さく, 地域愛 着（選好）から地域愛着（持続願望）に対する間接効果 の方が大きいため, 一概に観光への肯定的な態度が地域 愛着（持続願望）に影響を及ぼすとは単純には言えない ことに留意する必要がある.

\section{7. おわりに}

本研究では, (1)観光客の来訪地域に対する愛着意識 のモデル構造, (2)観光地住民の観光への態度尺度の構 成と地域愛着意識への影響, (3)観光地住民の地域愛着 意識のモデル構造について, 北海道ニセコ地域を対象と した調査分析を行った.

その結果, 以下の知見が得られた. まず, 観光客と地 域住民のどちらも想定した地域愛着（選好）から地域愛 着（感情）・地域愛着（持続願望）への正の有意なパス が見られたことから，地域を好きだと思う地域愛着（選 好）の醸成を通して, より深い段階の地域を大切と感じ る地域愛着 (感情) や「変わらないでほしい」という 
願いである地域愛着（持続願望）の醸成へつながる構造 が存在することが示唆された。

次に, 観光客の地域愛着には, 年齢, 国籍, 来訪地域 住民との交流度, 来訪回数, 来訪満足度が影響すること がわかった. さらに, 来訪目的による差異も見られ, 自 然景観や地域の人とのふれあいを求めて来る観光客は, その地域への愛着が高いという結果となった. 一方で, 温泉を目的として来訪した人は, 他の人に比べて地域愛 着が低いという結果となった。これは温泉は一施設であ り，地域の独自性がそれほど高くないことが影響してい る可能性が考えられる.この仮定に立つと，スキーも同 様の結果となると予想されるが，スキー目的ダミーから 地域愛着（選好）には負の影響が示されたものの，地域 愛着（感情）には有意な正のパスが示された. このよう に来訪目的と地域愛着の関係については, 本研究におけ る調查分析からは不明な部分もあり, 今後, さらなる調 査分析が必要である.

また，観光地に居住する住民の観光への態度について は，「観光が景観，治安，交通状況に与える影響に対す る好意的評価度」「観光が文化交流, 歴史遺産等に与え る影響に対する好意的評価度」「観光が公共施設・サー ビスへ与える影響に対する好意的評価度」「観光が経済, 商業活動に与える影響に対する好意的評価度」の 4 つの 観光に対する評価軸が影響しあって, 観光への態度が構 成されることが示唆された.

続いて, この尺度を用いて地域住民の地域愛着の構造 モデルについて共分散構造分析を行った結果, 居住年数 と地域との交流度, 地域活動への参加有無が地域愛着に 有意な影響を与えることが示唆された．しかし，居住年 数に関しては, 地域愛着（持続願望）には負のパスが示 されたことから, 単純に居住年数が長ければ長いほど地 域愛着が高くなるとは言えず，地域での経験の質が地域 愛着の醸成により大きな影響を与える可能性を示してい るとも言える. このことは, 地域との交流度や地域活動 への参加度が地域愛着に正方向の因果関係が認められる ことからも一定の妥当性を持つと推察される.

そして, 観光への態度が地域愛着に与える影響につい て, 地域の観光に対して肯定的であるほど，地域愛着 （選好）は高いが，地域愛着（持続願望）は低くなると いう結果となった．これは，観光に対して好意的である ことは地域を好きだという初期段階の地域愛着は高くな るが，地域にそのままの姿でいてほしいという願いには 負の影響を与える，すなわち，地域が変化することを求 めている，ということを意味している. つまり, 観光推 進を願う人は，地域を変えたいと思っている可能性を示 唆しており, 観光が地域に対してダイナミックな変化を 与えるものであることを暗示しているとも言えよう。一 方で, 地域の伝統や歴史を尊重し「地域に変わって欲し
くないものがある」という気もち，すなわち持続願望は, 地域のあり方そのものに対して”願い”を抱く地域愛着の 一種とされている. よって, 観光化を進める場合, それ まで地域が培ってきた歴史や環境，コミュニティ等に配 慮する必要があり, 急速な観光開発により地域が大きく 変化するようなことがあれば, 持続願望という地域愛着 が低下寸る要因になり得る可能性を示しているといえる.

今後の課題として, 本研究では検証できなかった, 外 国人と日本人の地域愛着意識の構造モデルの差異や, 居 住年数と地域愛着の関係性, 観光地の型(観光資源など) の差による結果の差異などを検証することを挙げたい. 他にも, 観光地は発展期や成熟期, 停滞期, 衰退期など その状況は多様である. そのため, 観光地の特性によっ てどのような差異があるのか事例を蓄積し検討寸る必要 がある，その上で，観光客も住民もその地域に愛着と敬 意を持ち合うような，よりよい観光地をつくるための方 途を模索していきたいと考えている.

謝辞 : 本研究で実施したインタビュー・アンケート調查 は, シーニックバイウェイ北海道の中村幸治氏の全面的 な協力を得て実施したものである. また, 二セコ町・俱 知安町の皆さまにはインタビュー調査, アンケート調査 に快くご協力いただいた。 ここに記して謝意を表す。

\section{注}

[1]本研究で地域愛着の規定因として挙げた「来訪回 数」や「まちづくり活動への参加」は地域愛着の䤑成結 果である可能性も考えられる. 本研究で行った共分散構 造分析のモデルでは, 便宜的に地域愛着に影響する要因 として扱っているが，どちらの方向の因果関係も想定で きる.

\section{参考文献}

1) 観光庁 : 観光立国推進基本計画, 2009.

2) イーフー・トゥアン, 山本浩訳 : 空間の経験一身体 から都市一, 筑摩書房, 1993. 原著 Yi-Fu Tuan: Space and Place - The perspective of Experience, Minneapolis: University of Minnesota Press, 1977.

3) エドワード・レルフ, 高野岳彦・阿部隆・石山美也 子訳 : 場所の現象学一没場所性を越えて, 築摩書房, 1991. 原著 Edward Relph: Place and Placelessness, London: Pion, 1976.

4) Vaske, J. and Kobrin, K.: Place attachment and Environmental responsible behavior, The Journal of Environmental Education, Vol. 32, No. 4, pp. 16-21, 2001.

5) 真鍋知子：地域愛着心の規定要因一地域生活環境評 価を中心として一, 人間文化研究科年報, 奈良女子 大学大学院人間文化研究科, 1996.

6)引地博之, 青木俊明: 地域に対する愛着形成の心理 過程の検討, 景観・デザイン研究講演集, No. 1, 2005.

7) Brown, G., Brown, B. and Perkins, D.: New housing as 
neighborhood revitalization - place attachment and confidence among residents-, Environmental and Behavior, Vol. 36, No. 6, pp. 749-775, 2004.

8）鈴木春菜，藤井聡：地域愛着が地域への協力行動に 及ぼす影響に関する研究, 土木計画学研究・論文集, Vol. 25-2, pp. 357-362, 2008.

9) 谷口守, 松中亮治, 芝池綾：ソーシャル・キャピタ ル形成とまちづくり意識の関連, 土木計画学研究・ 論文集，Vol. 25, pp. 311-318, 2008.

10) 深見聡, 井出明 編 : 観光とまちづくり一地域を活か 寸新しい視点一, 古今書院, 2010 .

11) McCool, S. F. and Martin, S. R.: Community attachment and attitudes toward tourism development, Journal of Travel Research, Vol. 32, No. 3, pp. 29-34, 1994.

12) 宮原英種, 宮原和子：観光心理学を愉しむ一観光行 動のしくみを解明する ツーリズム・サイコロジー, ナカニシヤ出版, 2001 .

13) 前田勇, 佐々木土師二, 小口孝司: 観光の社会心理 学一ひと, こと, もの 3 つの視点から, 北大路書房, 2006.

14) 佐々木土師二：観光旅行の心理学, 北大路書房, 2007.

15) 山下晋司 : 観光人類学, 新曜社, 1996.

16) Brown, B., Perkins, D. and Brown, G.: Place attachment in a revitalizing neighborhood: Individual and block levels of analysis, Journal of Environmental Psychology, Vol. 23, pp. 259-271, 2003.

17) Hidalgo, M. and Hernendez, B.: Place attachment, conceptual and empirical questions, Journal of Environmental Psychology, Vol. 21, pp. 273-281, 2001.

18）萩原剛, 藤井聡 : 交通行動が地域愛着に与える影響 に関する分析, 土木計画学研究・講演集, Vol. 32 (CD-ROM), 2005.

19) Payton, M., Fulton, D. and Anderson, D.: Influence of Place Attachment and Trust on civic action: A study at Sherburne National Wild Refuge, Society \& Natural Resources, Vol. 18, pp. 511-528, 2005.
20）大谷華，芳賀繁：地域交通環境の利用が高齢住民の 地域感情に及ぼす影響, 立教大学心理学研究, Vol. 45, pp.01-09, 2003.

21) Davis, D. L., Allen, J. and Cosenza, R. M.: Segmenting local residents by their attitudes, interests, and opinions toward tourism, Journal of Travel Research, Vol. 26, No. 3, pp. 2-8, 1988.

22) Getz, D.: Impacts of tourism on residents' leisure: Concepts, and a longitudinal case study of Spey Valley, Scotland, Tourism Management, Vol. 15, No. 4, pp. 247$258,1993$.

23) Johnson, J. D., Snepenger, D. J. and Akis, S.: Residents' perception of tourism development, Annals of Tourism Research, Vol. 21, No. 3, pp. 629-642, 1994.

24) Liu, J. C., Sheldon, T. V. and Var, T.: Resident perception of the environmental impacts of tourism, Annals of Tourism Research, Vol. 14, No. 1, pp. 17-27, 1987.

25) Lankford, S. V.: Attitudes and perceptions toward tourism and rural regional development, Journal of Travel Research, Vol. 32, No. 3, pp. 35-43, 1994.

26）小口孝司，大橋泰二：「面食い」は「推進派」? 観光事業への態度を規定する社会心理学的個人差に 関する研究, 日本観光研究学会第 12 回大会論文集, pp. 1-6, 1997.

27) 佐々木土師二：ツーリズムのインパクトと地域住民 の態度一観光心理学で取り残された課題に関する文 献の概観, 関西大学社会学部紀要, Vol. 37, No. 3, pp. 197-269, 2006.

28）国土交通省：観光投資に関する調查 - 研究報告書, 2007.

29) Twigger-Ross, C. L. and Uzzell, D. L.: Place and Identity Processes, Journal of Environmental Psychology, Vol. 16, pp. 205-220, 1996.

\title{
STUDY ON PLACE ATTACHMENT OF STAKEHOLDERS RELATED TO TOURIST SPOT—CASE STUDY ON NISEKO AND KUCCHAN AREA
}

\author{
Ayako TANIGUCHI, Yui IMAI, Fumihiro HARA and Haruo ISHIDA
}

Recently, tourism becomes the important policy in Japan. Therefore, it is necessary to examine effects of tourism not only quantitative effects to regional economy but also the qualitative effects such as the improvement of the local place attachment in future. In this study, we conducted surveys to verify how the tourism effect the stakeholder's place attachment as a case study of Niseko-Kucchan area.

The result showed that the exchanges with local residents had a significant positive effect on the place attachment of tourists. In addition, it was shown that the more active local residents did exchanges with their neighbors and participated in community action, the higher the place attachment of local residents was. It was also shown that the residents' attitude toward tourism was consist of four elements, "Landscape and Public peace", "Culture and Tradition", "Public facilities and Public service", "Economy and Commercial activity". It was shown that the residents' positive attitude toward tourism had positive effect on the preference to their place. But on the sustainment desire toward the residential place, the residents' positive attitude toward tourism had negative effect. 